\title{
A Temperate Phage Specific for Female Strains of Escherichia coli $\mathrm{x} 12$
}

\author{
By A. HAKURA, N. OTSUJI AND Y. HIROTA \\ Department of Biology, School of Science and The Research Institute \\ for Microbial Diseases, Osaka University, Japan
}

(Received 24 September 1963)

\begin{abstract}
SUMMARY
A temperate bacteriophage named ' $t a u$ ' which forms plaques on $\mathbf{F}$ strains but not on $\mathrm{F}+$ strains of Escherichia coli $\mathrm{x} 12$ has been isolated. This phage adsorbs equally well to $\mathbf{F}+$ and $\mathbf{F}-$ strains, which indicates that some later step of the growth cycle is inhibited by the presence of the sex-factor $\boldsymbol{F}$. The frequency of lysogenization of the phage is also affected by the $\boldsymbol{F}$ factor. The genetic material of phage tau may be DNA. The phage is $40-50 \mathrm{~m} \mu$ in diameter.
\end{abstract}

\section{INTRODUCTION}

Genetic studies with Escherichia coli have shown that some transmissible elements such as the temperate phage lambda (Lederberg \& Lederberg, 1953), the sex-factor $F$ (Lederberg, Cavalli \& Lederberg, 1952; Hayes, 1953) and colicinogenic factors (Fredericq, 1948, 1953) show certain common features in their behaviour. These are named 'episomes' (Jacob \& Wollman, 1958). It is well known that lysogenic bacteria are not susceptible to infection by phage particles which are homologous with the phage lysogenized. This phenomemon is ascribed to the presence of a prophage on the bacterial chromosome which is homologous to the superinfecting temperate phage. Various temperate phages, such as lambda or $\mathbf{P 1}$, interfere with the growth of the $\mathbf{T}$ series of phages when they are present as prophages in their hosts (Benzer, 1955; Lederberg, 1957). If analogous phenomena could be found between different episomic elements, such as the $\boldsymbol{F}$ factor and temperate phages, the interaction between them might open the way to further understanding of their nature. For this reason, we have searched for temperate phages which have some relationship to the sex-factor $\boldsymbol{F}$ of $\boldsymbol{E}$. coli.

Recently, Zinder (1961) succeeded in isolating a phage which grows in female $(\mathrm{F}-)$, but not in male $(\mathrm{F}+$ or $\mathrm{Hfr}$ ) strains of Salmonella typhimurium. The present paper describes a new temperate phage named 'tau' which forms plaques on $\mathbf{F}$ strains but not on $\mathbf{F}+$ or $\mathbf{F}^{\prime}$ (F prime) strains (Hirota \& Sneath, 1961; Jacob, Schaeffer \& Wollman, 1960). Preliminary studies were reported previously (Hakura \& Hirota, 1961).

\section{METHODS}

Nutrient broth used for these experiments consisted of $10 \mathrm{~g}$. Kyokuto meat extract, $10 \mathrm{~g}$. polypeptone and $2 \mathrm{~g}$. $\mathrm{NaCl}$. in 1 l. distilled water; adjusted to $\mathrm{pH} \mathrm{7 \cdot 2.}$ Nutrient agar plates were prepared from the same medium $+1 \%$ agar. In some 
experiments, tris + glucose medium was used. This contained: tris $10^{-2} \mathrm{M} ; \mathrm{Na}_{2} \mathrm{HPO}_{4}$, $5 \times 10^{-4} \mathrm{M} ; \mathrm{CaCl}_{2}, 10^{-3} \mathrm{M} ; \mathrm{MgSO}_{4} 7 \mathrm{H}_{2} \mathrm{O}, 10^{-3} \mathrm{M} ; \mathrm{FeCl}_{3}, 10^{-5} \mathrm{M}$; Casamino acid, $2 \mathrm{~g}$; $\mathrm{NaCl}, 5$ g.; $\mathrm{NH}_{4} \mathrm{Cl}, 1 \mathrm{~g}$.; glucose 3 g.; in 1 l. distilled water; adjusted to $\mathrm{pH} \mathbf{7 \cdot 2}$.

The characteristics of Escherichia coli $\mathrm{x} 12$ and its various mutants used in these experiments are summarized in Tables 1 and 2. Strains of $E$. coli independently isolated from clinical specimens were obtained from the Research Institute for Microbial Diseases, Osaka University, and tested for lysogenicity. Single colonies grown on Bacto S-S agar medium were spotted on a nutrient agar plate which was to serve as master plate in testing lysogenicity of bacteria isolated. After incubation for $16 \mathrm{hr}$ at $37^{\circ}$, the master plate was replica-plated on soft agar containing strain 58-161 F+or strain $\mathrm{Y}-70 \mathrm{~F}-$. The replica plate was exposed to ultraviolet light ( $15 \mathrm{~W}$. Toshiba germicidal lamp) for 40 sec. at a distance of $45 \mathrm{~cm}$. and then incubated at $37^{\circ}$ for $14 \mathrm{hr}$. Colonies on the master plate corresponding to inhibition zones were picked out and their properties examined.

\section{RESULTS}

Among eighty-four lysogenic strains isolated, it was found that two strains released bacteriophages which formed plaques only on $\mathbf{F}-$ strains but not on $\mathbf{F}+$ strains of Escherichia coli $\mathrm{K} 12$. Both phages appeared to be closely related, if not identical, by the criteria of plaque morphology, latent period, burst size, and immunity to superinfection. Therefore, only one of these phages was used for the succeeding experiments; it was named ' $t a u$ '.

Table 1. The relationship between growth of phage tau and the presence of the sex-factor $F$ of Escherichia coli

\begin{tabular}{|c|c|c|c|c|c|c|}
\hline \multirow[b]{2}{*}{ Strain } & \multicolumn{5}{|c|}{ Genotype* } & \multirow[b]{2}{*}{$\begin{array}{l}\text { Response to } \\
\text { phage tau }\end{array}$} \\
\hline & $\begin{array}{l}\text { Nutritional } \\
\text { requirement }\end{array}$ & $\begin{array}{l}\text { Sugar fer- } \\
\text { mentation }\end{array}$ & $\mathbf{L p}$ & $\mathbf{S}$ & $\operatorname{Sex}$ & \\
\hline w 4574 & $\mathbf{P}^{-}$ & $\begin{array}{l}\operatorname{Ara}_{2}^{-} \mathrm{Xyl}_{2}^{-} \mathrm{Mal}_{1}^{-} \\
\mathrm{Mtl}^{-} \mathrm{Gal}_{2}^{-} \mathrm{Lac}_{85}^{-}\end{array}$ & + & $r$ & $\mathbf{F}-$ & + \\
\hline$J E-23 \dagger$ & $\mathrm{P}^{-}$ & $\begin{array}{l}\mathrm{Ara}_{2}^{-} \mathrm{Xyl}_{2}^{-} \mathrm{Mal}_{1-}^{-} \\
\mathrm{Mtl}^{-} \mathrm{Gal}_{2}^{-} \mathrm{Lac}_{85}^{-}\end{array}$ & + & $r$ & $\mathbf{F}+$ & - \\
\hline w 3110 & Prototroph & Fermenter & - & $s$ & $\mathbf{F}-$ & + \\
\hline JE-24† & Prototroph & Fermenter & - & $s$ & $\mathbf{F}+$ & - \\
\hline $58-161$ & $\mathbf{M}^{-}$ & Fermenter & + & $s$ & $\mathbf{F}+$ & - \\
\hline JE-25† & $\mathbf{M}^{-}$ & Fermenter & + & $s$ & $\mathbf{F}-$ & + \\
\hline
\end{tabular}

* The abbreviations of genetic markers used here are as follows: $P$, proline; $M$, methionine; Lp, prophage lambda; $\boldsymbol{F}$, sex factor; Ara, arabinose; Xyl, xylose; Mal, maltose; Mtl, mannitol; Gal, galactose; Lac, lactose; $\mathrm{S}$, Streptomycin, $r$ or $s$ indicate resistance or sensitivity.

$\dagger \mathrm{JE}-23$ and $\mathrm{JE}-24$ were isolated from $\mathrm{w} 4573$ and $w 3110$ after infection with $F$ factor.

$\ddagger$ JE-25 was isolated from 58-161 by eliminating $F$ factors (Hirota \& Iijima 1957).

An experiment was done to determine the growth of the phage on different strains of Escherichia coli $\mathbf{K}$ 12. As seen from Table 1, plaques of the phage were formed on all the $\mathbf{F}$ - strains used, but not on any of the $\mathbf{F}+$ strains tested. These results indicate that formation of plaques of the phage is prevented by the $\mathbf{F}$ factor, and bacterial characteristics such as sugar fermentation, drug resistance, nutritional requirements, or the presence or absence of prophage lambda are not associated with the capacity of the phage tau to form plaques. 
To test this hypothesis two experiments were carried out. In one experiment, an $\mathbf{F}$ - strain which could support growth of the phage was converted into an $\mathrm{F}+$ strain by infection with the $F$ factor from an $F+$ strain. It was found that as a result of its conversion from $\mathbf{F}-$ to $\mathbf{F}+$, the strain lost its ability to support growth of phage tau. In the other experiment, $\mathrm{F}$ - strains were isolated from an $\mathrm{F}+$ strain after growth in the presence of acridine (Hirota \& Iijima, 1957). These F - strains, in contrast to the original $\mathrm{F}+$ strain, supported growth of the phage. These results further show that for growth of the phage in the host cells the sex-factor $F$ must be absent.

Table 2. Comparison on the efficiency of adsorption of phage tau to Escherichia coli $\mathrm{K} 12 \mathrm{~F}+$ and $\mathrm{F}-$

Exponentially growing broth cultures of $\mathrm{Y}-70$ and JE-26 were centrifuged and resuspended in the same volumes of broth. They were infected with the phage at a multiplicity of about $10^{-2}$, and incubated at $37^{\circ}$ for $30 \mathrm{~min}$. and then were centrifuged at 5000 r.p.m. for $10 \mathrm{~min}$. Phage particles remaining in the supernatant were assayed by plating on $\mathrm{F}-$.

\begin{tabular}{|c|c|c|c|c|}
\hline Strain & $\begin{array}{l}\text { No. of cells } \\
\text { per ml. }\end{array}$ & $\begin{array}{l}\text { Phage particles } \\
\text { added }\end{array}$ & $\begin{array}{l}\text { Multiplicity } \\
\text { of infection }\end{array}$ & $\begin{array}{l}\text { Adsorbed } \\
\text { phage }\end{array}$ \\
\hline $\mathrm{Y} \cdot 70^{*}$ & $2 \cdot 3 \times 10^{8}$ & $1.8 \times 10^{7}$ & $7 \cdot 4 \times 10^{-2}$ & $1.2 \times 10^{7}$ \\
\hline JE-26† & $3.2 \times 10^{8}$ & $1.8 \times 10^{7}$ & $5.6 \times 10^{-2}$ & $1.2 \times 10^{7}$ \\
\hline
\end{tabular}

Table 3. The effect of the $F$ factor on lysogenization of phage tau

Exponentially growing broth cultures of $\mathbf{F}-, \mathbf{F}^{\prime}$ and $\mathbf{F}+$ strains were mixed with a phage lysate which had been prepared by u.v.-irradiation of JE- 103 for induction of phage tau. The mixtures were incubated at $37^{\circ}$ for $30 \mathrm{~min}$. and then washed twice with distilled water to remove unadsorbed free phage. They were then resuspended in the original volume of broth.

Appropriate dilutions of these infected cells were spread on individual nutrient agar plates, andincubated at $37^{\circ}$ overnight. Colonies formed on these plates were replica-plated to nutrient agar plates which had been overlaid with $0.55 \%(w / v)$ soft agar containing one drop of an overnight broth culture of w 3110.

The replica plates were exposed to u.v.-light ( $15 \mathrm{~W}$. of Toshiba germicidal lamp) for 20 sec. at a distance of $45 \mathrm{~cm}$, and then incubated at $37^{\circ}$ for $14 \mathrm{hr}$.

Where colonies were lysogenized by the phage, zones of inhibition of growth appeared around the replica-plated colonies.

$\begin{array}{lccc}\text { Multiplicity of infection } & 3 \cdot 3 & 3 \cdot 6 & 3 \cdot 4 \\ \text { No. of colonies lysogenized } & 41 & 1 & 3 \\ \text { No. of colonies tested } & 128 & 79 & 100\end{array}$

* F- used: w 3110, Lp $\mathrm{p}^{\mathrm{s}}$ Prototroph F-.

$\dagger$ F+ used: JE- 24, w 3110 carrying $F$ factor.

$\ddagger F^{\prime}$ used: $J E-340$, w 3110 carrying an $F$ prime, $F_{8}$.

The inability of the phage to grow on $\mathbf{F}+$ strains might have been due to its failure to be adsorbed, $\mathbf{F}$ - but not $\mathbf{F}+$ bacteria having a specific receptor for the phage, as occurs with Escherichia coli $\mathrm{B} / 2$ and phage T2. The data presented in Table 2 indicate that the phage adsorbs to $\mathrm{F}+$ strains as efficiently as to $\mathrm{F}-$ strains. Therefore, it was concluded that the growth cycle of the phage is inhibited at some later stage by the presence of the sex-factor $F$. 
The $\mathbf{F}+$ strain as well as the $\mathbf{F}$ - strain may become lysogenic with the phage. Ultraviolet (u.v.) irradiation or treatment with mitomycin $\mathrm{C}$ induces growth of the phage in lysogenic cells. The frequency of lysogenization by the phage of $\mathbf{F}-$ and $\mathbf{F}+$ strains were compared. As shown in Table 3, the phage lysogenized a smaller proportion of $\mathbf{F}+$ and $\mathbf{F}^{\prime}$ cells than $\mathbf{F}$ - cells under these experimental conditions. This result indicates that the $F$ factor inhibits not only plaque formation but also lysogenization. A one-step growth curve of the phage after u.v.- induction of an F - strain of Escherichia coli lysogenized by phage $t a u$ was made. The progeny was released after a latent period of about $120 \mathrm{~min}$. and 200 infective particles/bacterium were obtained. The sedimentation constant of purified phage was measured in a Spinco analytical ultra-centrifuge, Model $\mathbf{E}$. There was a single schlieren peak and the sedimentation constant was about $200 \mathrm{~S}$. Electronmicrographs of this phage shows an approximately spherical particle of $40-50 \mathrm{~m} \mu$ diameter.

\section{DISCUSSION}

We can assume that the genetic material of phage tau is injected into $\mathrm{F}+$ cells, since the phage adsorbs equally well to $\mathbf{F}+$ as $\mathbf{F}$ - strains of Escherichia coli, and can lysogenize $\mathbf{F}+$ as well as $\mathbf{F}$ - strains, although with different efficiencies. It is well known that lysogenic bacteria are immune to superinfection by homologous phage. To explain the immunity of the lysogenic bacteria, it is assumed that there exists a cytoplasmic repressor in lysogenic bacteria, which inhibits multiplication of homologous temperate phages (Jacob \& Campbell, 1959). The relationship between the $F$ factor and the phage may be somewhat analogous to the phenomenon seen in the lysogenic bacteria. By analogy, we may assume that the $F$ factor directs the synthesis of a cytoplasmic repressor which inhibits multiplication of phage tau.

Loeb \& Zinder (1961) reported that the bacteriophage specific for F+ strains of Escherichia coli contain RNA. Preliminary experiments indicate that phage tau contains DNA, but it is not yet possible to give exact values for the amount of DNA/phage particle, because of difficulties in obtaining pure preparations without loss of plaque-forming capacity (Otsuji, 1961).

Recently two other bacteriophages which are capable of growth on F - but not on $\mathbf{F}+$ strains have been isolated (Iijima \& Eguchi, personal communication). One of these shows the same immunity as phage tau, but the other one is able to grow in bacteria which were lysogenized with phage tau. Such lysogenic bacteria carrying different kinds of prophage, the growth of which is affected by the $F$ factor, may be used as tools for genetic analysis of the $F$ factor; experiments on this are in progress.

The authors wish to express their appreciation to Professors H. Kikkawa and J. Kawamata for their interest and encouragement in this work. This paper was supported in part by research grants, GM 08293, from the National Institutes of Health, U.S. Public Health Service, and the Waksman Foundation of Japan. 


\section{REFERENCES}

Benzer, S. (1955). Fine structure of a genetic region in bacteriophage. Proc. nat. Acad. Sci., Wash. 41, 344.

FredericQ, P. (1948). Actions antibiotiques réciproques chez les Enterobacteriaceas. Rev. Belge. Path. suppl. 4.

Frederica, P. (1953). Colicines et bactériophages. Annls Inst. Pasteur Paris, 84, 294.

Hakura, A. \& Hirota, Y. (1961). Sex-determining temperate phage tau in Escherichia coli к-12. Jap. J. Genet. 36, 379.

HAYES, W. (1953). Observations on a transmissible agent determining sexual differentiation in Bacterium coli. J. gen. Microbiol. 8, 72.

Hinota, Y. \& IrJima, T. (1957). Acriflavine as an effective agent for eliminating $F$ factor in Escherichia coli $\mathrm{K}-12$. Nature, Lond. 180, 655.

Hiro'tA, Y. \& SNEATH, P. H. A. (1961). $\mathbf{F}^{\prime}$ and F mediated transduction in Escherichia coli к-12. Jap. J. Genet. 36, 307.

Jacos, F. \& CAMpbell, A. (1959). Sur le système de répression assurant l'immunité chez les bactéries lysogènes. C.r. hebd. Séanc. Acad. Sci., Paris, 248, 3219.

JAcob, F., Schaeffer, P. \& Wollman, E. L. (1960). Episomic elements in bacteria. Symp. Soc. gen. Microbiol. 10, 67.

J hebd. Séanc. Acad. Sci., Paris, 247, 154.

LEDERBERG, S. (1957). Suppression of the multiplication of heterologous bacteriophages in lysogenic bacteria. Virology, 3, 496.

Lederberg, J., Cavalit, L. L. \& Lederberg, E. M. (1952). Sex-compatibility in Escherichia coli. Genetics, 37, 720.

Lederberg, E. M. \& Lederberg, J. (1953). Genetic studies of lysogenicity in Escherichia coli. Genetics, 38, $\mathbf{5 1}$.

Loeb, F. \& Zinder, N. D. (1961). A bacteriophage containing RNA. Proc. nat. Acad. Sci., Wash. 47, 282.

Otsusi, N. (1961). Physical and chemical properties of temperate phage tau. Jap. J. Genet. 36, 392.

ZiNDER, N. D. (1961). A bacteriophage specific for F- Salmonella strains. Science, 133. 2069. 